\title{
NOTES ON A REMARKABLE NUDIBRANCH FROM NORTH-WEST AMERICA.
}

\author{
By Sir Charles Eliot, K.C.M.G., C.B., etc.
}

Read 9th November, 1900.

Tне British Museum collection of Nudibranchs contains a remarkable specimen, preserved in alcohol, and labelled "Massett, Queen Charlotte's Island, British Columbia, Rev. J. Keen, $91: 7: 10$. 23-4." It has been examined by Dr. Willey and myself.

The length of the animal (Fig. I) is $7 \cdot 6$ centimetres, the breadth $3 \cdot 5$, and the height $2 \cdot 4$. The colour is a uniform brownish yellow, and the general shape Doris-like, both the head and tail being rounded, but the mantle is not continued round the head, and the anus $(a$.$) is lateral,$ as in Tritonia. There are two large rhinophores $(r h$.) retracted into pits, but not provided with any external sheaths. They show no traces of lamellation, and have no plumes or other appendages. They are somewhat wide apart, the distance between them being $1 \cdot 3 \mathrm{~cm}$. The mantle edge (m.f.) stops on each side of the body under the rhinophores, but is distinct all the way behind. It is narrow and not provided with any appendages, or with lamellæ underneath. The whole surface of the animal presents no traces of cerata, or other processes, or of injuries where such processes might have been detached.

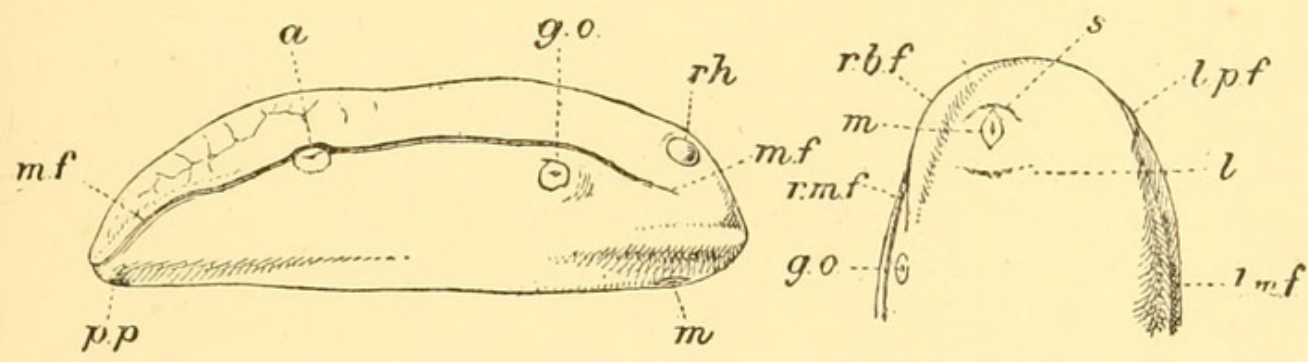

I.

II.

FIG. I. Animal viewed from the right side.

,, II. Ventral surface of anterior end.

a. anus.

g.o. genital orifice.

l. transverse line.

l.m.f. left mantle flap.

l.p.f. left pedal flap.

$m$. mouth. m.f. mantle flap.

p.p. pedal pit.

$r . b f$. right border of foot.

$r h$. rhinophore.

$r . m . f$. right mantle flap.

$s$. sinus.

The head parts bear a superficial resemblance to the cephalic shield of Scaphander or Philine. There are no oral tentacles, but a projecting rim without appendages seems to represent the trace of a frontal veil. The mouth $(m$.$) is a simple aperture without lips, and ventrally placed;$ above it is a crescent-shaped sinus (s.), and below it the faint indication of a transverse line $(l$. $)$, which does not, however, amount to a distinction between the pedal surface and the mouth parts. Hence the foot may 
be said to pass into the frontal veil, and the area surrounding the mouth is continuous with the sole. Dr. Willey and others who have examined the specimen agree in thinking that this conformation, though it may be teratological, is not due to distortion by alcohol. It is remarkable, however, that the anterior region is not symmetrical: the mouth is not in the median line of the foot, but to the left (looking at the animal ventrally), and the œsophagus and buccal mass are not directly behind the mouth, but to the left of it.

The buccal mass is large, and provided with strong jaws, somewhat similar to those of Tritonia Hombergi, but shorter and broader. The radula is similar to that of Tritonia, but with fewer teeth in the row than usual. The central tooth is like a truncated pyramid, the anterior margin having a slight cleft, the continuation of which forms a groove on the anterior side of the pyramid. The laterals are narrower, irregularly triangular, and each provided with a long process.

The liver is entire, and presents no diverticula, though it is divided by a hollow in which lie part of the intestine and the stomach. The nervous system, though not well preserved, appears to resemble that of Tritonia, but no trace of eyes was discernible. The reproductive system appears to be diaulic, and I could only discover one spermatheca.

It appears, therefore, that this specimen is an aberrant member of the Tritonia group, differing from others in the absence of branchiæ, of projecting rhinophore sheaths, and of all appendages, in the rounded shape of the head, and in the ventral position of the mouth. These remarkable characters are probably correlated with a burrowing habit.

Bergh, in Semper's "Reisen im Archipel der Philippinen," Thl. II, Bd. ii, p. 726, and in his tract on the Nudibranchiate Gasteropods of the North Pacific (Dall's "Scientific Results of the Exploration of Alaska," vol. i, 1879, p. 154, figs.), has described an animal dredged by Dr. Dall in 1872 at Unalashka, which he identifies with Tritonia tetraquetra, Pallas. Dr. Dall stated that the living animal had no gills, and none appear in the drawing by Pallas (in Nova Acta Acad. Sci. Petrop., tom. ii, 1788 , pp. 237-239, pl. v, fig. 22). Bergh considers that it can hardly be true that the living animal possessed no gills or appendages, ${ }^{1}$ but the present specimen seems to show that a large Nudibranch without gills is found in the North Pacific. Both the jaws and radula of our specimen correspond with those of Tritonia tetraquetra, but the ventral position of the mouth and the rounded shape of the head make it impossible to identify it with either Pallas's figure, or with Bergh's description of the animal obtained by Dr. Dall, which had also plumes around the rhinophores.

In a recently published paper ("Danish Ingolf Expedition," vol. ii, pt. 3, 1990, Nudibranchiate Gasteropoda), Bergh has described a remarkable new form, which he names Doridoxa Ingolfiana, and

1 It is not easy to reconcile the different statements respecting this animal, of which there was apparently only one specimen, for though Dr. Dall said it had no gills or appendages in life, and though in Semper's "Reisen" Bergh seems to say that they must have been rubbed off, yet in pl. iii, fig. 14, of the Nudibr. Moll. of the N. Pacific, the latter author gives a drawing of a gill. 
which he regards as a connecting link between the Dorididæ and Tritoniidæ. It possesses the following characteristics: a Doris-like shape, with ample pallial margin and narrowish foot; no projecting sheaths to rhinophores; strong jaws, and a multiseriate radula with central tooth; no gills of any kind; a lateral anus, a blood gland, and two spermathecas. The British Museum specimen certainly does not belong to the same genus, but it appears to form another link between the Dorididæ and Tritoniidæ. It agrees with Doridoxa in the absence of gills, appendages, and rhinophore sheaths, and in the rounded shape of the back. But the narrow pallial margin, the height of the body, and the absence of a blood gland and of a second spermatheca, are characters which approximate it to Tritonia. I should say, however, that, though I was unable to discover the two last-named organs, the interior of the animal was not well preserved, and their non-existence cannot be regarded as certain.

It is much to be desired that naturalists in British Columbia and Alaska should endeavour to obtain further specimens of the molluse dredged by Mr. Keen, because its peculiarities, if not teratological, are sufficient to constitute a new and remarkable genus. 


\section{$2 \mathrm{BHL}$ Biodiversity Heritage Library}

Eliot, Charles. 1901. "NOTES ON A REMARKABLE NUDIBRANCH FROM NORTH-WEST AMERICA." Proceedings of the Malacological Society of London 4, 163-165.

View This Item Online: https://www.biodiversitylibrary.org/item/53747

Permalink: https://www.biodiversitylibrary.org/partpdf/202769

\section{Holding Institution}

Smithsonian Libraries

\section{Sponsored by}

Smithsonian

\section{Copyright \& Reuse}

Copyright Status: Public domain. The BHL considers that this work is no longer under copyright protection.

This document was created from content at the Biodiversity Heritage Library, the world's largest open access digital library for biodiversity literature and archives. Visit BHL at https://www.biodiversitylibrary.org. 